\title{
THE ROLE OF REACTIVE OXYGEN SPESIES IN THE PATHOGENESIS OF EXPERIMENTAL MAXILLARY SINUSITIS
}

\author{
Yurii Andreychyn
}

\author{
Department of Otorhinolaryngology, Ophthalmology and Neurosurgery \\ of I.Ya. Horbachevsky Ternopil State Medical University
}

Andreychyn Y. (2014), The role of reactive oxygen spesies in the pathogenesis of experimental maxillary sinusitis. Health Problems of Civilization, 4 (8) p. 16-19

Summary: Simulated maxillary sinusitis was observed in guinea pigs following the surgical incision in superior cervical sympathetic ganglion. Additionally, toxic hepatitis development was stimulated after exposure to tetrachlormethane in experimental animals. The treated and control animals were observed for three months. A significant increase in the content of reactive oxygen species (ROS) in neutrophils and lymphocytes was noted in artificially developed sinusitis. The ROS values were slightly higher in the case of combined experimental sinusitis and toxic hepatitis. Based on the obtained data, the role of ROS in the development of sinusitis was discussed.

Keywords: sinusitis, hepatitis, reactive oxygen species

\section{Introduction}

Sinusitis belongs to common diseases in the world. About 3 million people suffer annually from acute sinusitis in Ukraine. The incidence is approximately 250 cases per 10 thousand (Деменков et al. 2013). Chronic sinusitis may develop following prolonged exposure to adverse factors (Betlejewski 2008). The high incidence of sinusitis requires studying pathogenesis of the disease, including causes and molecular interactions involved, as sinusitis was insufficiently studied so far (Боєнко 2013, Деменков 2013, Завалий М.А., Безшапочный С.Б. 2010, Меusel 2010, Zmijewski et al. 2009).

It is known that activation of free radical oxidation of lipids plays an important role in the pathogenesis of many diseases, including sinusitis. One of the factors that initiates lipid peroxidation is reactive oxygen species (ROS) - hydrogen peroxide, hypochlorite, oxygen radicals, superoxide and hydroxyl radical, which are produced during phagocytosis by polymorphonuclear leukocytes. Disorders of oxygen metabolites synthesis by phagocytes are related to the causes of respiratory system diseases. The products which are accumulated after partial reduction of oxygen include superoxide anion, which together with NO forms mediators of oxidative cell damage, including peroxynitrite. Those compounds damage proteins, lipids of cell membranes and the vascular endothelium, increasing platelet aggregation, and causing the processes of endotoxemia. The ROS also play an important role in the body protection from various harmful factors as they are involved in the oxidation and detoxification of various exogenous and endogenous compounds. They have antibacterial properties and affect immune system. In the process of phagocytosis, macrophages use ROS for the removal of phagocytized bacteria and destruction of cells infected by viruses. Macrophages destroy old or immunologically compromised cells, including malignant cells (Gilbert Daniel, Colton Carol, 2002, Губский 2006).

\section{The objective of study}

The objective of our study was to investigate the role of ROS in the pathogenesis of maxillary sinusitis using the experimental model of guinea-pigs.

\footnotetext{
Adress for correspondence: Yurii Andreychyn, I.Ya. Horbachevsky Ternopil State Medical University, m.Voli, 1, Ternopil, 46001, e-mail: university@tdmu.edu.ua, phone: +380 352524492

Tables: 2 Figures: 1 References: 17 Full-text PDF www.hpc.edu.pl Copyright (C) Pope John Paul II State School of Higher Education in Biała Podlaska, Sidorska 95/97, 21-500 Biała Podlaska Indexation: Index Copernicus, Database AGRO, ProQuest, Polish Ministry of Science and Higher Education. This is an open-access article distributed under the terms of the Creative Common Attribution Non-commercial license (http://creativecommons.org/licenses/by-nc/3.0), which permits use, distribution and reproduction in any medium, provided the original works is properly cited, the use is non-commercial and is otherwise in compliance with the license.
} 


\section{Materials and methods}

The experiments were performed on 84 guinea-pigs weighing 800-1200 g, which were fed standard vivarium diet. The animals were divided into three groups: (1) control (intact animals), (2) animals with maxillary sinusitis, (3) guinea-pigs with sinusitis and toxic hepatitis. Each group included 28 animals. Maxillary sinusitis was modeled according to our method. The guinea-pigs were undergone the cross-section of the upper cervical sympathetic ganglion on the left side of the neck which leaded to disruption of trophic function of the sympathetic innervation and development of inflammatory and degenerative processes particularly in the maxillary sinus mucosa. Formation of the inflammatory and degenerative process was confirmed by histological examination of the affected tissues. Toxic hepatitis was modeled using a mixture of carbon tetrachloride: olive oil at a ratio of 1:1 introduced into experimental animal at $2 \mathrm{ml} / \mathrm{kg}$ by subcutaneous injection for two days.

The animals were euthanized on the 15, 35, 75 and 90-th day of the experiment. Euthanasia was performed by complete bloodletting from the heart, after using thiopental sodium anesthesia $\left(60 \mathrm{mg} / \mathrm{kg}^{-1} \mathrm{body}\right.$ weight intraperitoneally). Blood was used for the measurement of ROS.

As we were using animals as a model, we followed international standards of humane treatment of them in accordance with the rules of the «European Convention for the protection of vertebrate animals used for experimental and other scientific purposes» (European Convention, 1984) and methodological recommendations of the Ministry of Public Health of Ukraine «Preclinical studies of drugs» (2001).

The level of ROS in neutrophils was measured using dihydrofluorescein diacetate (DHF-DA) («Sigma Aldrich», USA), which is a fluorescent probe. After passive penetration into the cell and cleavage of acetate groups by esterases, DHFDA becomes dihydrofluorescein. The interaction of hydrogen peroxide and other free radicals with dihydrofluorescein causes its molecular transformation into fluorescein, a highly fluorescent compound. For an assay, $90 \mu \mathrm{l}$ of neutrophils suspension and $10 \mu \mathrm{l}$ of DHF-DA working solution were placed in a test tube. Cells were resuspended and incubated for $20 \mathrm{~min}$ at $37^{\circ} \mathrm{C}$. Following $10 \mathrm{~min}$ centrifugation step at $1000 \mathrm{rpm}$, the supernatant was separated and added to $400 \mu \mathrm{l}$ of phosphate-saline buffer. The samples were placed on ice; the level of ROS production was analyzed by fluorescence intensity of the dye at the FL-1 channel using cytofluorimeter Epics XL («Beckman Coulter», USA). The values of the analyzed parameter were expressed in \% (Li et al.2012, Дамбаева 2001).

Separation of neutrophils and lymphocytes was done by the density gradient centrifugation method.

Estimation of the differences reliability between groups was performed using the Uilkoksona-Mann-Whitney nonparametric method. Mathematical and statistical analysis of the digital data was done using Statistica program.

\section{Results and discussion}

ROS content in neutrophils of guinea-pigs with experimental sinusitis was 1.73 times greater compared to control on the 15-th day $(\mathrm{P}<0.02$, table 1$)$, while on the 90th day this index was 2.22 times higher $(\mathrm{P}<0.01$, table 1$)$. In the experimental group with both sinusitis and toxic hepatitis, the values were significantly higher compared to animals with sinusitis alone (for both day $15^{\text {th }}$ and day $90^{\text {th }}, \mathrm{P}<0.05-0.001$ ).

Table 1. Dynamics of ROS concentration in neutrophils of guinea-pigs with experimental maxillary sinusitis and toxic hepatitis (M $\pm m$ )

\begin{tabular}{|c|c|c|c|c|c|c|}
\hline \multirow{2}{*}{ Days } & \multicolumn{5}{|c|}{ Animal groups } & \multicolumn{3}{|c|}{ Indicator of reliability } \\
\cline { 2 - 7 } & control & sinusitis & $\begin{array}{c}\text { sinusitis and toxic } \\
\text { hepatitis }\end{array}$ & P1 & P2 & P3 \\
\hline 15-th & $34,44 \pm 0,68$ & $59,69 \pm 3,96$ & $68,29 \pm 0,21$ & $<0,001$ & $<0,001$ & $<0,05$ \\
\hline 35-th & $34,84 \pm 0,70$ & $68,55 \pm 2,34$ & $69,34 \pm 0,41$ & $<0,001$ & $<0,001$ & $>0,05$ \\
\hline 75-th & $34,24 \pm 0,63$ & $78,00 \pm 0,81$ & $79,57 \pm 1,24$ & $<0,001$ & $<0,001$ & $>0,05$ \\
\hline 90-th & $34,42 \pm 0,46$ & $76,35 \pm 1,61$ & $83,17 \pm 1,22$ & $<0,001$ & $<0,001$ & $<0,001$ \\
\hline
\end{tabular}

Note. Here and in the next table: P1 - between control and guinea pigs with sinusitis, P2 - between control and guinea pigs with sinusitis and hepatitis, P3 - between animals with sinusitis and sinusitis plus hepatitis.

In the lymphocytes of the healthy guinea pigs the concentration of ROS remained at the same level during the entire experiment (table 2), however, for the guinea pigs with sinusitis this parameter increased 1.7-2.2 times (15-th-90-th day, $\mathrm{P}<0.02-0.001)$.

In case of the combined pathology (sinusitis and hepatitis), the level of ROS increased in comparison to sinusitis alone on the 15-th, 75-th and 90-th day of the experiment $(\mathrm{P}<0.02-0.03)$. 
Table 2. Dynamics of ROS concentration in lymphocytes of guinea-pigs with experimental maxillary sinusitis and toxic hepatitis (M $\pm \mathrm{m}$ )

\begin{tabular}{|c|c|c|c|c|c|c|}
\hline \multirow{3}{*}{ Days } & \multicolumn{3}{|c|}{ Animal groups } & \multirow{2}{*}{\multicolumn{3}{|c|}{ Indicator of reliability }} \\
\hline & \multirow{2}{*}{ control } & \multirow{2}{*}{ sinusitis } & \multirow{2}{*}{$\begin{array}{c}\text { sinusitis and toxic } \\
\text { hepatitis }\end{array}$} & & & \\
\hline & & & & $\mathrm{P}_{1}$ & $\mathrm{P}_{2}$ & $\mathrm{P}_{3}$ \\
\hline 15 -th & $23,05 \pm 0,75$ & $43,76 \pm 3,46$ & $50,31 \pm 0,87$ & $<0,001$ & $<0,001$ & $<0,05$ \\
\hline 35-th & $23,14 \pm 0,79$ & $59,45 \pm 1,19$ & $59,27 \pm 0,22$ & $<0,001$ & $<0,001$ & $>0,05$ \\
\hline 75-th & $22,71 \pm 0,72$ & $64,23 \pm 0,38$ & $67,33 \pm 0,67$ & $<0,001$ & $<0,001$ & $<0,01$ \\
\hline 90-th & $23,28 \pm 0,54$ & $65,68 \pm 0,86$ & $71,93 \pm 0,65$ & $<0,001$ & $<0,001$ & $<0,001$ \\
\hline
\end{tabular}

Comparative analysis (Fig. 1) has shown that the animals of all groups (healthy, with experimental sinusitis, and with sinusitis plus hepatitis) on the 15-th day of the experiment had greater ROS concentration in neutrophils compared to lymphocytes. Similar differences were also noted in another terms of experiment (days 35,75 and $90, \mathrm{P}<0.05-0.01$ ).

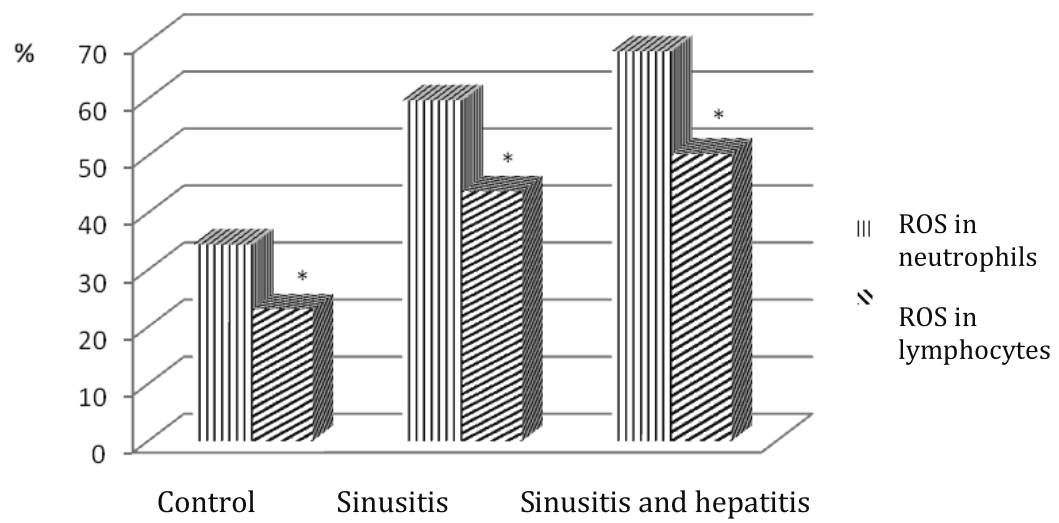

Figure 1. Comparison of ROS content in white blood cells of guinea-pigs of different groups on the 15th day of the experiment. Note: ${ }^{*} \mathrm{P}<0.05-0.01$ between the neutrophils and lymphocytes.

Incision of the cervical sympathetic ganglia causes stress in animals. Oxidative reactions, which are accompanied by an increase in ROS concentration and stimulation of free radical oxidation, play the important role in the stress (Hiwari et al. 2002). Activation of molecular oxygen in sinusitis may be due to the high level oxygen concentration in the affected tissues as well as hypoxia and accumulation of reduced pyridine nucleotides forms and catecholamines, increase of their precursors and metabolites concentration, enhanced metabolism of arachidonic acid, activation of myeloperoxidase in phagocytes, decreased activity of enzymes of antioxidant system and levels of endogenous antioxidants, etc. (Голод Е.А., Кирпатовский В.И. 2003, Melley 2005). ROS damage proteins, lipids, DNA, leading to disruption of the structure and function of cell membranes and microcirculation (Looney M. R. 2009). Increased concentrations of nitric oxide and superoxide radicals cause damage of mitochondria, the energy deficit and death of cell (Новиков et al. 2008). This process promotes activation of microorganisms that penetrate the sinuses and cause inflammatory changes. The increase of ROS also occurs in toxic hepatitis and other liver diseases. The decrease of antitoxic liver function causes the body's intoxication and results in the development of various inflammatory diseases (Когутич 2013). Thus, ROS can cause significant disorders of protein, lipid and nucleic acid metabolism in the affected tissues and ultimately deepen inflammatory and degenerative processes in the tissues, including the mucous membrane of maxillary sinus.

\section{Conclusions}

1. Maxillary sinusitis in guinea pigs caused by the surgical incision resulted in the increased ROS content in neutrophils, and to lesser extent, in lymphocytes.

2. The concentration of ROS had a tendency to increase in neutrophils and lymphocytes during three-months observation period in experimental animals.

3. A combination of both experimental toxic hepatitis and sinusitis in guinea pigs resulted in higher concentration of ROS in neutriphils and lymphocytes compared to the effect of sinusitis alone. 


\section{References:}

1. Betlejewski S., Betlejewski A. (2008), The influence of nasal flow aerodynamics on the nasal physiology. Otolaryngol. 62(3), 321-325.

2. Боєнко С.К., Шлопов В.Г., Толалаєнко І.О., Гладкова Н.О. (2012), Зміни рецепторного апарату слизової оболонки передньої групи навколоносових пазух при хронічних синуситах. Ринологія. 2, 3-8.

3. Gilbert Daniel L., Colton Carol A. (2002), Reactive Oxygen Species in Biological Sistems. An interdisciplinary Appriach. 707 p.

4. Hiwari B. S., Belenghi B., Levine A. (2002), Oxidative stress increased respiration and generation of reactive oxygen species, resulting in ATP depletion, opening of mitochondrial permeability transition, and programmed cell death. Plant Physiol. 128, 4, 1271-1281.

5. Голод Е.А., Кирпатовский В.И. (2003), Повышение уровня активных форм кислорода как одна из причин нарушения метаболизма в клетках почечных канальщев у больных острым и хроническим пиелонефритом. Урология. 1, 59-61.

6. Губский Ю. И., Беленичев И.Ф., Павлов С.В., Левицкий Е.Л., Бухтиярова Н.В. (2006), Роль активных форм кислорода в патогенезе синдрома пренатального стресса. Современные проблемы токсикологии. 2, 37-42.

7. Деменков И.В. (2013), Эффективность использования йоддицерина в комплексном лечении больных острыми гнойными синуситами. Ринологія. 1, 55 -58.

8. Деменков И.В., Приставко Т.М., Деменков В.В., Ватанская И.Ю. (2013), Неинвазивные методы лечения больных острым гнойным гайморитом: за и против. Журнал вушних, носових і горлових хвороб. 5-С, 66-67.

9. Завалий М.А., Безшапочный С.Б. (2010), Анализ клинических симптомов физико-химических показателей функции мукоцилиарной транспортной системы у больных острым гнойным синуситом. Ринологія. 4, 3-14.

10. Когутич А. I. (2013), Клініко-імунологічні особливості хронічного гепатиту С у поєднанні з хронічним обструктивним захворюванням легень і ефективність галоаерозольтерапї: автореф. дис. ... канд. мед. наук. Київ, 20 с.

11. W. Li, H. Liu, J. S. Zhou [et al.] (2012), Caveolin-1 Inhibits Expression of Antioxidant Enzymes through Direct Interaction with Nuclear Erythroid 2 p45-related Factor-2 (Nrf2). J. Biol. Chem. 287, 25, 20922-20930.

12. Дамбаева С.В., Мазуров Д.В., Пинегин Б.В. (2001), Оценка продукции активных форм кислорода методом проточной цитометрии в клетках периферической крови человека. Иммунология. 6, 58-61.

13. Looney M. R. (2009), Neutrophil sandwiches injure the microcirculation. Nat. Med. 15, 4, 364-366.

14. Melley D. D., Evans T. W., Quinlan G. J. (2005), Redox regulation of neutrophil apoptosis and the systemic inflammatory response syndrome. Clin. Sci. Vol. 108, 5, 413-424.

15. Meusel T., Negoias S., Scheibe M., Hummel T. (2010), Topographical differences in distribution and responsiveness of trigeminal sensitivity within the human nasal mucosa. 151(2), 516-521.

16. Новиков А.К., Бердникова Н.Г., Воейкова В.Л. (2008), Исследование в динамике уровня активных форм кислорода в крови пациентов с обструктивными заболеваниями легких и его значение в оценке эффективности фармакотерапии. Клиническая фармокология и терапия. 17, 5, 24-28.

17. Zmijewski J. W., Lorne1 E., Xia Zhao [et al.] (2009), Antiinflammatory effects of hydrogen peroxide in neutrophil activation and acute lung injury. Am. J. of Respiratory and Critical Care Medicine. 179, 8, 694-704. 